\title{
Development of outcomes based national road and rail safety performance measures
}

\author{
B. P. Hughes ${ }^{1} \&$ S. Hopkins ${ }^{2}$ \\ ${ }^{1}$ Curtin - Monash Accident Research Centre, Curtin University, Australia \\ ${ }^{2}$ Centre for International Health, Curtin University, Australia
}

\begin{abstract}
Transport delivers many benefits to the community, business, the environment and government. Yet transport agencies tend to monitor and report on activities and outputs rather than the real outcomes which are rarely measured. Management theory and practice has developed to measure performance in order to improve organisational efficiency and effectiveness, which can therefore be applied to transport.

This paper reports the foundations for transport performance measurement and safety measures prepared for the Australian National Transport Commission (NTC) which sought to develop outcomes based performance measures. The basis is an understanding of the current and developing theory and practice in performance measurement and a description of the context. A framework for performance measures, including criteria for selection, and content requirements provides the outline for the safety measures. The paper concludes with a description of the road and rail performance measures which were developed.

The overview of the development of outcomes based performance measurement for road and rail safety provided in this paper summarises the information to develop practical measures for transport which can be used for policy and operations management. The information is relevant for transport policy agencies, regulators, infrastructure owners and operators, primarily in government, but also in the private sector.

Keywords: road, rail, safety, performance, management, outcome, output, activity, transport, organisation.
\end{abstract}




\section{Introduction}

\subsection{Australian road and rail transport background}

Australian transport is as diverse and extreme as anywhere in the world. Land transport in Australia includes nearly every combination of governance and operations, including government and private ownership of roads and railways, both for operations and infrastructure. Major railways are self sufficient, while roads and public transport require government funding in various forms.

Australian road and rail operations are some of the largest and most sophisticated in the world. There are some of the world's largest freight rail and trucking operations through to tiny tourist and heritage railways. One of the world's largest passenger rail networks by length is in Sydney, and one of the world's largest tram networks is in Melbourne. Some operations are in very remote areas, hundreds of kilometres from cities. Australians cities are sparse, covering large footprints resulting in long commuter distance with congestion which will dramatically increase in future. Increases in population and economic activity are high compared to other developed countries. Extreme environmental conditions vary from floods in tropical areas, arid hot regions which easily buckle railways to snowfields where main roads are closed in winter.

Australia continues to face major transport challenges. Population, vehicle travel, freight transport, traffic delays and congestion costs are all projected to continue to grow for the foreseeable medium term future. These impacts will occur provided the future improvements to transport systems which have been achieved continue as successfully as they have been in the past. However due to many constraints, this continues to be increasingly difficult.

Given these increases in demand, and the consequences which result for transport operations, significant challenges to safety are expected. For instance, as vehicle travel increases by $18 \%$, a commensurate reduction in the crash or severity rate will be required just to keep the number of people killed or seriously injured at the same level as they are currently. The typical objective of reducing this human cost will require increases greater than $1.7 \%$ per annum in the safety rates.

\subsection{The role of Australian government in road and rail transport}

All three levels of government in Australia; national (Australian or Commonwealth government), State and Territory, and local government (cities, towns and shires) have responsibilities for aspects of road and rail transport which may not be consistent. For instance, one State operates freight railways while other States do not. These are complex and inconsistent arrangements which vary, but are generally as summarised in Table 1 .

In practice, these responsibilities are undertaken co-operatively between the levels of governments and with the private sector. There are many formal and informal agreements, as well as working arrangements, which facilitate cohesive management of the land transport. 
Table 1: Typical Australian road and rail transport responsibilities.

\begin{tabular}{|c|c|c|c|c|}
\hline & $\begin{array}{l}\text { Australian } \\
\text { Government }\end{array}$ & $\begin{array}{c}\text { State or Territory } \\
\text { Government }\end{array}$ & Local Government & Private \\
\hline $\begin{array}{c}\text { Road } \\
\text { Transport }\end{array}$ & $\begin{array}{l}\text { National policy. } \\
\text { Funding. } \\
\text { Vehicle Standards. } \\
\text { Pricing. }\end{array}$ & $\begin{array}{l}\text { State road policy, } \\
\text { planning, design, } \\
\text { construction and } \\
\text { maintenance. } \\
\text { Bus operations. } \\
\text { Pricing. } \\
\text { Vehicle, driver \& } \\
\text { access regulation. } \\
\text { Enforcement. }\end{array}$ & $\begin{array}{l}\text { Local road planning, } \\
\text { design, construction } \\
\text { and maintenance. } \\
\text { Access regulation. }\end{array}$ & $\begin{array}{c}\text { Operations, including } \\
\text { safety. } \\
\text { Contract } \\
\text { maintenance. }\end{array}$ \\
\hline Rail Transport & $\begin{array}{l}\text { National policy. } \\
\text { Funding. } \\
\text { Rolling stock and } \\
\text { infrastructure } \\
\text { standards. }\end{array}$ & $\begin{array}{l}\text { Safety, access and } \\
\text { pricing regulation. } \\
\text { Public transport } \\
\text { including operations } \\
\text { and safety. } \\
\text { State rail policy, } \\
\text { planning, design, } \\
\text { construction and } \\
\text { maintenance. }\end{array}$ & & $\begin{array}{l}\text { Operations, including } \\
\text { safety. } \\
\text { Planning, design, } \\
\text { construction and } \\
\text { maintenance. } \\
\text { Ownership. } \\
\text { Funding. } \\
\text { Rolling stock and } \\
\text { infrastructure } \\
\text { standards. }\end{array}$ \\
\hline
\end{tabular}

Transport outcomes are not solely the responsibility of government transport agencies. There are often different government agencies for policy, regulation (safety and economic), infrastructure and operations. Other non-transport agencies in government can also affect transport (such as treasury, workplace safety, or environment). Transport is thus affected by many agencies policies and operations. Consequently, there are many factors and influences which impinge transport safety which are important to recognise, some of which include social, economic, and land use considerations.

Safety of railway infrastructure and operations is regulated by individual State Governments operating co-operatively under a co-regulatory regime based on monitoring and ensuring outcomes, but not by specifying particular actions. Australian Governments are moving towards a single national rail safety regulator.

Road safety responsibilities are generally distributed amongst transport and road safety agencies for policy and co-ordination, State and local government road agencies for infrastructure and some operations, and Police for enforcement. Other participants include health and justice departments, or insurance commissions.

\subsection{The national transport commission}

NTC's transport objectives are categorised as transport productivity and efficiency, safety and environmental performance. As an agency it also sought to 
measure its performance in terms of regulatory efficiency and to improve its own organisational strategies internally. Based on these objectives, and partly in response to an organisational review that was conducted, the NTC sought to measure the performance of land transport reforms in five categories. The measures were intended to be 'outcomes-based' as opposed to reporting 'activity' or 'outputs', and were also intended to improve reporting consistency.

In its submission to its review, the NTC (National Transport Commission (NTC) [1]) makes the critical observation that: "The next phase of transport reform will be challenging as the focus shifts from improving individual modes to lifting the performance of the national transport system as a whole. Reform development needs to holistically consider impacts on productivity, safety, pricing, network access and land-use planning and investment." So, the future direction of transport reform in Australia can be expected to be much more complicated than in the past, and not limited to regulation, individual outcomes, particular agencies, modes in isolation, or separate activities. This multifaceted perspective is challenging to agencies with relatively narrow responsibilities in terms of mode (e.g. road or rail), type of activity (e.g. infrastructure, operations regulation or policy), or outcome (e.g. transport or environment).

\subsection{Study of performance reporting of transport reform outcomes}

NTC engaged the Curtin - Monash Accident Research Centre (C-MARC), with subcontractors to:

Identify and recommend a balanced set of transport indicators and methodologies to report progress against NTC's objectives; and

Provide advice on performance measures to measure the delivery of organisational strategies; particularly those strategies not currently measured.

This study (Hughes [2]) was undertaken by desktop research and covered all areas of NTC's objectives noted above, although only the safety indicators are reported here. The study followed the following stages:

1. Collection of relevant Australian and international academic and government policy background material;

2. Summary of Australian transport reporting in each outcome category;

3. Description of relevant background and case examples of performance reporting;

4. Development of a framework for reporting with criteria for selection of measures and descriptions of specifications;

5. Preparation of performance measures for the five categories of outcomes; and

6. Reporting on the study's conclusions with liaison with NTC staff.

During the study there was no external consultation with government agencies or other interests. The study aimed to propose performance indicators which are relevant to responsibility, valuable and consequently have a purpose. NTC intends to take the information and proposals for performance measures to its stakeholders in government and beyond, for development and agreement. 


\section{Safety performance measurement and management}

\subsection{Modern management practice}

Over the last thirty years, many countries have moved their public accountability requirements from a traditional emphasis on managers' stewardship of public resources through monitoring inputs, processes and outputs to a performance framework where there is greater emphasis on achieving efficient and effective outcomes. Performance management, or results based management, can be defined as a broad management strategy aimed at achieving important changes in the way government or public agencies operate, with improving performance or achieving better results as the central orientation (Kristensen, Groszyk [3]). In this process, measures of performance have played a key role in reporting the achievement of progress against organisational objectives.

An underlying methodology for outcomes-based accountability is program logic (also known as 'logic model', 'logical framework'). The distinction between outputs and outcomes is important. Outputs are goods and services that directly result from the production process undertaken by firms, governments or households (economic units) such as transportation of goods by road and train and travel to work by private vehicles and public transport. An output-focus typically describes public functions in terms of goods or services and calculates how many services are being delivered, or products produced. It is primarily oriented to indicators such as volume and timeliness, and to a varying degree, quality.

Outcomes, on the other hand, are situations that consumers and society values, such as safe journeys, low road congestion and efficient and effective delivery systems. Such delivery systems mean, amongst other things, that consumers pay lower prices for goods and services and receive fresher products such as meat and vegetables. Outcomes are not always the result of production processes themselves. Outcomes can be broken down into direct and indirect outcomes, the distinction being that direct outcomes are closer to the act of service provision than indirect outcomes and can be affected in the short-term by policy changes. For example, in the case of public transport, policy change may bring about more utilisation of public bus services. A direct outcome of the policy change may be more and better intra-urban bus services which are of more value to consumers but in the longer term the indirect outcomes may be improved health status and lower health care expenditures due to less road congestion and associated air and noise pollution.

One of the key differences between outputs and outcomes is the measurement of performance against objectives. The Australian Treasury (Australian Government [4]) defines outcomes as the "intended results, impacts or consequences of actions by the Government on the Australian community. Agencies deliver programs which are the Government actions taken to deliver the stated outcomes."

Outputs are most frequently monitored by indicators of efficiency: technical and economic (or allocative). Performance measurement against outcomes 
requires an assessment of efficiency and effectiveness, both technical and economic. Performance measurement is concerned with the production or supply of performance information, and is focused on technical aspects of clarifying objectives, developing indicators, and collecting and analysing data on results. Performance indicators are intended to change the way organisations operate to improve the efficiency and effectiveness of delivery of benefits to the community and business, by encouraging behavioural change. People in organisations respond to measurement. Measures send people messages about what matters and how they should behave. When the measures are consistent with the organisation's strategies they encourage behaviours that are consistent with strategy.

Performance management encompasses performance measurement, but is broader. As in performance measurement, it is concerned with generating management demand for performance information - that is, with its uses in program, policy, and budget decision-making processes and with establishing organisational procedures, mechanisms and incentives that actively encourage its use. In an effective performance management system, achieving results and continuous improvement based on performance information is central to the management process (OECD The Development Assistance Committee (DAC) Working Party on Aid Evaluation [5]).

In the Australian context, the NTC shares accountability with governments for monitoring and evaluating performance measures, and at the same time contributes to understanding, managing and influencing key performance areas where it has no direct role (such as planning). This will ensure transport reform priorities are identified and pursued holistically.

The study proposed that performance measures should be chosen to describe outcomes which are valued by the community and governments. The criteria also aim to meet the functionality and administrative requirements for transport agencies.

\subsection{Criteria for performance measures}

The criteria proposed to select indicators for performance reporting, based on these requirements and best practice are:

Policy relevance;

Accessibility;

Representativeness and validity;

Reliability;

Simplification; and

Outcomes-focus.

The criteria used to choose the performance measures ensure they are relevant and valid, and represent value, both in an outcomes sense for the community and governments, and in an administrative sense for transport agencies. This position is based on several underlying propositions including that performance reporting is not an end in itself but provides information which contributes to management decisions which result in greater achievement of transport benefits. Performance 
measures should focus on outcomes representing underlying real value to Australia, not merely reflecting agency deliverables (output), or process (activity). To be useful, these measures must be practical and useful to the agency and relate to the management of objectives and transport problems to be overcome.

Preparation of performance measures in this way allows relativity and comparison between road and rail transport, between different categories of performance, between different jurisdictions, between different levels of government and between different functions. It also allows integration of performance measurement using the same data for several purposes and reporting of a cohesive and complete view of transport outcomes.

\section{Framework for road and rail safety performance measures}

Many of the most recent and current safety strategies follow the 'Safe System' approach (Elvik et al. [6]), (Road Safety Council [7]), which focuses on the key elements of users (drivers, passengers, riders and pedestrians), infrastructure (predominantly roads, signs and signals, road sides), vehicles and energy (represented by speed management). These four constructs are based on evidence of the main elements of the transport system which contribute directly to crashes.

The reasons for the need for safety performance indicators, and improvements to them, have been summarised as (European Transport Safety Council (ETSC) [8]) being to:

Report on the underlying, long-term expected performance while random shortterm fluctuations occur;

Report on safety accurately when reporting errors can routinely and systematically occur;

Understand the processes that lead to accidents, in order to develop effective measures to reduce the number of accidents and injuries;

Indicate emerging problems at an early stage, before large scale effects occur;

Help illustrate how well road safety programs are doing in meeting their objectives or achieving the desired outcomes; and

Track progress and possibly provide a basis to evaluate and improve performance.

\subsection{Current transport performance measurement practice}

The survey of available information internationally, undertaken as part of this project, suggests a complete reporting package would describe performance measures in the context of strategic objectives, national and state descriptions, and sector descriptions (including transport).

The review also indicated that most agencies reported activity levels and/or outputs, rather than outcomes valued by users or the community. While there were many commonalities between performance measures, there were just as many differences, as well as inaccuracies and variations in definitions. Most 
agencies tended to report on what was relevant to their span of control and most measures which agencies reported on were not the sole responsibility of the agency. Agencies typically reported activities and outputs, but few outcomes which were directly beneficial to users. There were several difficulties in reporting transport performance at a national level for exactly the same reasons. Most performance measures had some validity, but were not, and could not, be completely coherent with respect to responsibility. Consequently, as far as possible, it was intended to measure the performance of what is important and what can be managed, while recognising shared responsibility.

\subsection{Proposed specifications for performance indicators}

Based on the background, of current practice and modern management, the following specifications were set for the chosen performance measures:

Title of the indicator;

Purpose;

Object of measurement;

Metric and Direction;

Data Requirements;

Data Collection Methods;

Timing (short or long-term indicator, or delay in reporting);

Ownership (data source and reporting agency);

Reliability;

Relationships Links;

Future Developments; and

Other Relevant Information.

\section{Australian safety performance reporting practice}

A survey of Australian transport, road and rail agencies, organisations and companies revealed a substantial variety of performance measures relevant to safety. Typical Australian road and rail safety performance indicators are summarised in Table 2. Reports from similar agencies, departments and organisations outside Australia reveal similar results and issues. The Australian rail safety regulators currently co-operate through the Australian Rail Safety Regulators Panel (RSRP) which co-ordinates consistency of practice and provides guidelines for safety reporting by railways.

These indicators reveal several issues for performance reporting including diversity, non-conformity and relevance. There are few indicators which are commonly reported by different companies, departments or organisations so it is difficult to compare across similar situations. Few indicators are relevant to both road and rail, even though such comparisons are important for policy decisions.

Some of the indicators report levels of activity (e.g. number of inspections), others report outcomes (e.g. the number of deaths). Perhaps encouragingly, these indicators generally do not report on outputs, which are typical in other transport agency performance reporting (e.g. the length of road constructed). 
Table 2: Typical Australian road and rail transport safety performance indicators.

\begin{tabular}{|c|c|c|}
\hline Road Transport & Rail Transport & $\begin{array}{c}\text { Public Transport (both road } \\
\text { and rail) }\end{array}$ \\
\hline 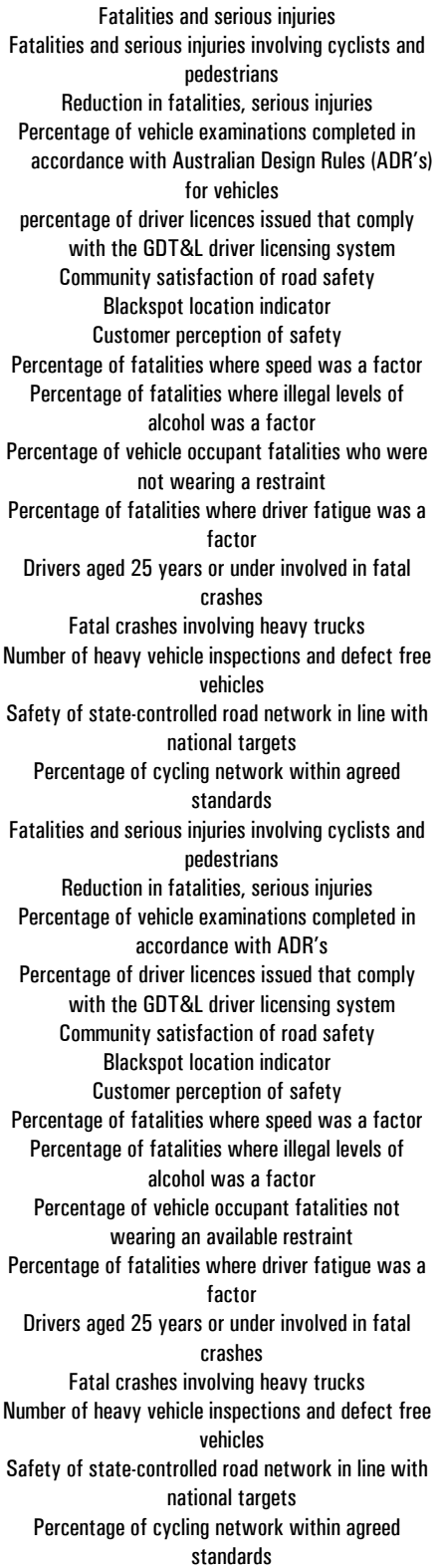 & $\begin{array}{c}\text { Number of deaths (non-suicide) } \\
\text { Number of serious injuries } \\
\text { Number of derailments } \\
\text { Number of collisions } \\
\text { Number of level crossing collisions } \\
\text { Number of loading irregularities } \\
\text { Number of track/infrastructure } \\
\text { irregularities } \\
\text { Alcohol or drugs test results } \\
\text { Number of collisions on running line } \\
\text { Number of fires } \\
\text { Number of load irregularities } \\
\text { Number of rolling stock irregularities } \\
\text { Number of safeworking rule or } \\
\text { procedure breaches } \\
\text { Number of trespasses } \\
\text { Passenger incidents: fall rate } \\
\text { Employee incidents: passenger assaults } \\
\text { Driver suspensions } \\
\text { Rail safety audits conducted } \\
\text { satisfactorily } \\
\text { Rail safety inspections conducted } \\
\text { satisfactorily } \\
\text { Percentage of people who perceive } \\
\text { public transport is safe } \\
\text { Lost time injuries rate } \\
\text { Lost time injury severity rate } \\
\text { Signals Passed at Danger (SPAD's) rate } \\
\text { Reported crimes against the person } \\
\text { Customer incidents } \\
\text { Rate of serious rail accidents } \\
\text { Level of notifiable safety incidents } \\
\text { Safety incidents per million passengers } \\
\text { decrease } \\
\text { Number of notifiable occurrences } \\
\text { Return-to-work rate } \\
\text { Percentage of managers trained in OSH } \\
\text { and injury-management } \\
\text { responsibilities }\end{array}$ & \begin{tabular}{|} 
Percentage of people who perceive \\
public transport is safe, \\
Passenger fatalities, \\
Passenger serious injuries, \\
Satisfaction with personal safety, \\
Passenger fatalities and serious injuries, \\
Passenger incidents, \\
Employee incidents: passenger assaults, \\
Driver suspensions: number of drivers \\
suspended annually, \\
Drug and alcohol testing: total tests \\
conducted, total positive tests \\
recorded
\end{tabular} \\
\hline
\end{tabular}


An underlying issue not evident in the reports is that the definitions of many indicators are not described. Further investigation suggested that while some indicators may have the same name, they have different definitions in different situations (e.g. the level of serious injury). Clearly, there are simply a great number of indicators, which may well be useful for management at the operational level. However, at the strategic level of government there are probably too many indicators.

In addition to safety, developers of transport policy and decision makers have other issues to take into account including economic, political, social and environmental considerations. It is easy to repeat the common mantra 'Safety is our Highest Priority', when is it not possible to have zero harm within the constraints and requirements being placed on the system as a whole and with many stakeholders affected diversely.

The situation in Australia with respect to reporting of road safety information is almost identical to Europe (SafetyNet [9]) where critical issues included: fatalities being the only comparable measure of reporting, widely different definitions of severity; and significant underreporting of non-fatal crashes. Sweden and The Netherlands have adopted visionary targets of zero for the number of people killed and seriously injured, while the United Kingdom has adopted more pragmatic targets.

Crashes, deaths and serious injuries are reasonably rare in railways and occur across many locations, under varying operating conditions and with diverse contributing factors. To take account of differing sizes and operations of railways, rail safety data in Australia is 'normalised', collected and published on a jurisdictional basis. The normalising data was train kilometres; freight train kilometres; passenger train kilometres; and total track kilometres.

\section{Proposed road and rail performance measures}

The primary objective of transport safety is to eliminate the number of people killed and seriously injured. However, other measures are often used, particularly rates and activities. Intermediate measures may also be relevant, such as the number of vehicles with five star crash rating. The performance measures selected for reporting of road and rail safety are summarised in Table 3.

The safety performance measures proposed are strategic, relating directly to the four pillars of Safe Systems which are proposed to be used for the Australian National Road Safety Strategy (Department of Infrastructure Transport Regional Development and Local Government [10]); Safe Roads, Safe Speeds, Safe People and Safe Vehicles. The measures are adaptable to different circumstances. For instance, they are scalable to individual jurisdictions, regions or more specific modes (trucks, cars, etc).

The measures proposed recognise the primary measure of transport safety as the number of people killed and seriously injured. Other measures proposed, such as rates, are useful for comparative purposes. Intermediate measures, proposed are relevant to particular perspectives and activities such as the number of vehicles with five star crash rating which relates directly to 'Safe Vehicles'. 
Not all of the measures can be reported at the present time, and some require a relatively small amount of work to collect data, or agree on definitions, or collate. Other measures would benefit from refinements over time and still others require considerable debate, development and effort to report. For instance, the number of people seriously injured is not reported in all Australian jurisdictions.

Table 3: $\quad$ Proposed road and rail transport safety performance measures.

\begin{tabular}{|c|c|c|}
\hline Safety Performance Indicator & Purpose & Object \\
\hline $\begin{array}{l}\text { 1. Fatalities and Serious Injuries } \\
\text { 1.1 Road } \\
\text { 1.2 Rail }\end{array}$ & $\begin{array}{l}\text { To measure human impacts on } \\
\text { individuals in society }\end{array}$ & $\begin{array}{c}\text { The number of people killed and } \\
\text { seriously injured }\end{array}$ \\
\hline 2. Safe Road Vehicles & $\begin{array}{l}\text { To indicate the improvements in } \\
\text { passenger vehicle safety which } \\
\text { are occurring }\end{array}$ & $\begin{array}{c}\text { The level of vehicle safety quality } \\
\text { of new passenger cars }\end{array}$ \\
\hline 3. Safe Roads & $\begin{array}{l}\text { To indicate the improvements to } \\
\text { road infrastructure to improve } \\
\text { safety which are occurring }\end{array}$ & $\begin{array}{l}\text { The level of safety quality of } \\
\text { roads }\end{array}$ \\
\hline \begin{tabular}{|l} 
4. Safe Drivers \\
4.1 Seatbelt use \\
4.2 Alcohol and drugs \\
(road drivers) \\
4.3 Alcohol and drugs \\
(train drivers)
\end{tabular} & $\begin{array}{l}\text { To indicate the level of driver } \\
\text { safety }\end{array}$ & Driver safety \\
\hline 5. Safe Speeds & $\begin{array}{c}\text { To indicate the level of safe road } \\
\text { use }\end{array}$ & Safe speed of road use \\
\hline 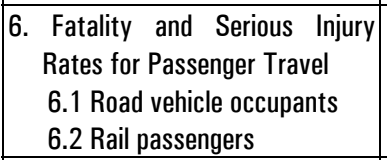 & $\begin{array}{c}\text { To understand relative levels of } \\
\text { passenger safety between modes } \\
\text { and related to travel }\end{array}$ & $\begin{array}{l}\text { The number of people killed and } \\
\text { seriously injured in passenger } \\
\text { vehicles compared with the } \\
\text { amount of passenger travel }\end{array}$ \\
\hline \begin{tabular}{|l} 
7. Fatality and Serious Injury \\
Rates for Freight Travel \\
7.1 Road freight \\
7.2 Rail freight
\end{tabular} & $\begin{array}{l}\text { To understand relative levels of } \\
\text { freight transport safety between } \\
\text { modes and related to travel }\end{array}$ & $\begin{array}{l}\text { The number of people killed and } \\
\text { seriously injured in crashes } \\
\text { involving freight vehicles } \\
\text { compared with the amount of } \\
\text { freight travel }\end{array}$ \\
\hline 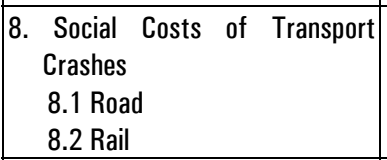 & $\begin{array}{l}\text { Economic costs are an important } \\
\text { measure for governments and for } \\
\text { comparisons with other sectors }\end{array}$ & $\begin{array}{l}\text { The total cost of crashes to the } \\
\text { community }\end{array}$ \\
\hline \begin{tabular}{|l|} 
9. Signal Violations \\
9.1 Rail Signals Passed at \\
Danger (SPAD) \\
9.2 Traffic control signal \\
violations \\
9.3 Railway level crossing \\
signal violations
\end{tabular} & $\begin{array}{l}\text { To measure the compliance of } \\
\text { drivers to control signals and } \\
\text { therefore the level of risk which } \\
\text { occurs }\end{array}$ & $\begin{array}{c}\text { The proportion of red control } \\
\text { signals which are passed by } \\
\text { drivers }\end{array}$ \\
\hline
\end{tabular}


There are currently differences in definition of several measures between jurisdictions which need to be harmonised and corrected in due course. There are also significant differences between road and rail transport in terms of government activity and reporting measures. However, there are many similarities in the reporting of performance. Therefore, relative reporting between the two modes is reasonable and can be improved with the introduction of more consistent measures (e.g. signal compliance for traffic signals and at railway level crossings).

The authors and NTC are confident that these measures are most appropriate to contribute to improved transport reform outcomes in future.

\section{Acknowledgements}

This paper is based on a project for the Australian National Transport Commission undertaken by a multidisciplinary project team with co-operation from senior staff at the NTC. The project leader was Brett Hughes and the NTC study manager was Paul Sullivan. Other key contributors to the project were Professor Sandra Hopkins, Caroline Evans, Jencie McRobert, Anusha Mahendran, Stuart Newstead, Angelo D'Elia, Dave Jones and Meena Naidu (NTC).

\section{References}

[1] National Transport Commission (NTC), 2009 Review of the National Transport Commission: Submission: Melbourne, 2009.

[2] Hughes, B.P., Performance Reporting of Transport Reform Outcomes. Curtin-Monash Accident Research Centre: Perth, Australia. p. 198, 2011.

[3] Kristensen, O.K., W. Groszyk, and B. Buhler, Outcome-focused Management and Budgeting. OECD Journal on Budgeting, 1(4), 2001.

[4] Australian Government, 2008-09 Treasury Portfolio Budget Statements Agency Budget Statements, Productivity Commission, Section 1: Agency overview and resources: Canberra, 2009.

[5] OECD The Development Assistance Committee (DAC) Working Party on Aid Evaluation, Results based management in the development cooperation agencies: a review of experience background report OECD, Editor, 2001.

[6] Elvik, R., et al., The Handbook of Road Safety Measures. 2nd ed, United Kingdom: Emerald Group Publishing Limited, 2009.

[7] Road Safety Council, Towards Zero - Road Safety Strategy, 2009.

[8] European Transport Safety Council (ETSC), Transport Safety Performance Indicators: Brussels, Belgium, 2001.

[9] SafetyNet, Building the European Road Safety Observatory, 2004.

[10] Department of Infrastructure Transport Regional Development and Local Government, National Road Safety Strategy; Draft for consultation: Canberra, 2010. 